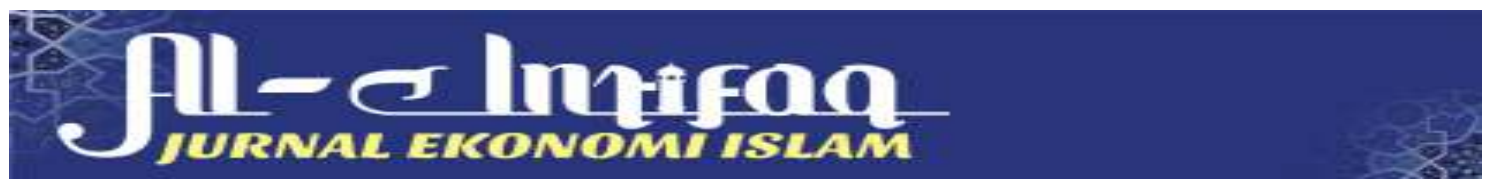

\title{
Pengaruh Pajak Daerah Dan Retribusi Daerah Terhadap Pendapatan Asli Daerah Kabupaten Lima Puluh Kota
}

\author{
Sri Amelia Rizki1 ${ }^{1}$, Ifelda Nengsih², Karmila Agustin ${ }^{3}$ \\ Fakultas Ekonomi dan Bisnis Islam, Institut Agama Islam Negri Batusangkar \\ amelia_rizki83@ymail.com ${ }^{1}$, ifeldanengsih@iainbatusangkar.ac.id ${ }^{2}$
}

\begin{abstract}
The purpose of the research that the authors do is to determine the effect of local taxes and levies on local revenue (PAD) in Fifty Cities District. This study uses a type of field study (field study) with a quantitative approach, the data source used in this study is a secondary data source, namely the Regional Financial Statements of Fifty Cities District, while the data collection technique used is the documentation technique. The results of the research by parameter estimates show that local taxes have an effect on the Regional Original Income (PAD) of Fifty Cities Regency. While the regional levies have no effect on the Regional Original Income (PAD) of Fifty Cities Regency. Simultally, the Pseudo R-Square test shows local taxes and The regional retribution affects the Regional Original Revenue (PAD) of Fifty Cities District.
\end{abstract}

Keywords: Local Taxes, Regional Levies and Local Own Revenue (PAD)

Abstrak: Tujuan dari penelitian yang penulis lakukan adalah untuk mengetahui pengaruh Pajak Daerah dan Retribusi Daerah terhadap Pendapatan Asli Daerah (PAD) Kabupaten Lima Puluh Kota. Penelitian ini menggunakan jenis penelitian fiel reaseach (studi lapangan) dengan pendekatan Kuantitatif, sumber data yang digunakan dalam penelitian ini adalah sumber data Skunder yaitu Laporan Keuangan Daerah Kabupaten Lima Puluh Kota, sedangkan teknik pengumpulan data yang digunakan adalah teknik Dokumentasi. Hasil penelitian secara Parameter Estimates menunjukan Pajak daerah berpengaruh terhadap Pendapatan Asli Daerah (PAD) Kabupaten Lima Puluh Kota.Sedangkan Retribusi daerah tidak berpengaruh terhadap Pendapatan Asli Daerah (PAD) Kabupaten Lima Puluh Kota.Secara Simultal yaitu uji Pseudo R-Square menunjukan Pajak daerah dan Retribusi daerah berpengaruh terhadap Pendapatan Asli Daerah (PAD) Kabupaten Lima Puluh Kota.

Kata Kunci: Pajak Daerah, Retribusi Daerah dan Pendapatan Asli Daerah (PAD)

\section{PENDAHULUAN}

Otonomi daerah merupakan suatu wewenang yang diberikan kepada suatu daerah untuk mengurus sendiri kepentingan dan kebijakan peraturan pemerintahan dan kepentingan masyarakat sesuai dengan peraturan Perundang-Undangan. (Mentayani dkk, 2014: 31). Sebagai otonomi daerah dituntut untuk dapat mengembangkan dan mengoptimalkan semua potensi daerah yang ada. Dari penggalian dan optimalisasi potensi yang ada pada daerah tersebut dapat diperoleh sebuah pemasukan bagi daerah itu sendiri dan dapat dikategorikan sebagai Pendapatan Asli Daerah (PsAD). Beberapa komponen Pendapatan Asli Daerah (PAD) 
adalah: pajak daerah, retribusi daerah, hasil pengelolaan kekayaan daerah yang dipisahkan, dan lain-lain PAD yang sah (Kusuma dan Wirawati, 2013: 575).

Pajak daerah merupakan salah satu sumber penerimaan utama bagi suatu daerah yang dibayar oleh masyarakat yang bersifat memaksa dengan berdasarkan Undang-undang yang digunakan untuk keperluan daerahnya. Retribusi daerah merupakan suatu pungutan yang dilakukan berkali-kali sepanjang masyarakat tersebut menggunakan jasa yang disedikan oleh pemerintah daerah.

Menurut penelitian yang pernah dilakukan oleh Kusuma dan Wirawati (2013) tentang Pengaruh penerimaan pajak daerah dan retribusi daerah terhadap Pendapatan Asli Daerah (PAD) di Kabupaten/Kota Bali menunjukan bahwa penerimaan pajak daerah dan retribusi daerah berpengaruh signifikan terhadap kenaikan dan penurunan Pendapatan Asli Daerah (PAD) Kabupaten/Kota Bali. Sedangkan menurut Ellysa Putri dkk. (2015) menjelaskan bahwa pajak daerah dan retribusi daerah berpengaruh terhadap Pendapatan Asli Daerah Kota Bandung dimana jika pendapatan pajak daerah dan retribusi daerah mengalami penurunan maka akan berpengaruh terhadap Pendapatan Asli Daerah juga mengalami penurunan dan sebaliknya jika pendapatan pajak daerah dan retribusi daerah mengalami kenaikan maka Pendapatan Asli Daerah akan mengalami kenaikan.

Alasan penulis memilih daerah Kabupaten LimaPuluh Kota karena memiliki perekonomian yang bagus jika dilihat dari usaha kecil menengah dan perindustriannya di Kabupaten Lima Puluh Kota sudah berkembang dengan baik dan dilihat dari bidang lain yaitu pada pariwisatanya Kabupaten Lima Puluh Kota banyak diminati oleh masyarakat luar untuk berkunjung ke wisata alam yang ada pada daerah tersebut. Dengan hal ini sangat membantu dalam kenaikan Pendapatan Asli Daerah khususnya pada sektor pajak daerah dan retribusi daerah Kabupaten Lima Puluh Kota.

Berdasarkan data yang ada, terlihat bahwa realisasi pajak daerah dan retribusi daerah belum mencapai target dikarenakan kurangnya kesadaran wajib pajak dalam melakukan pembayaran pajak dan retribusi daerah dan ada beberapa wajib pajak yang melakukan penunggakan terhadap pembayaran. Penelitian ini bertujuan untuk mengetahui pengaruh pajak daerah dan retribusi daerah terhadap Pendapatan Asli Daerah Kabupaten Lima Puluh Kota.

\section{KAJIAN TEORI}

\section{Pajak}

Pajak adala hiuran masyarakat kepada negara (yang dapat dipaksakan) yang terutang oleh yang wajib membayarnya menurut peraturan-peraturan umum(undang-undang) dengan tidak mendapatkan prestasi kembali yang langsung dapat ditunjuk dan yang gunanya adalah untuk membiayaipengeluaranpengeluaran umum berhubung tugas negara untuk menyelenggarakan pemerintahan (Adriani, $2013: 34$ ).

\section{Ciri-ciri Pajak}

Adapaun ciri-ciri pajak menurut Waluyo (2011 : 13) adalah sebagai berikut :

1. Pajak dipungut berdasarkan undang-undang serta aturan pelaksanaannya yang sifatnya dapat dipaksakan.

2. Dalam pembayaran pajak tidak dapat ditunjukan adanya kontrapretasi individual oleh pemerintah. 
3. Pajak dipungut oleh negara baik pemrintah pusat maupun pemerintah daerah.

4. Pajak diperuntukan bagi pengeluaran-pengeluaran pemerintah yang bila dari pemesukan masih terdapat surplus, dipergunakan untuk membiayai Public investment.

5. Pajak dapat pula mempunyai tujuan selain budgeter, yaitu "mengatur".

Agar pemungutan pajak tidak menimbulkan hambatan atau perlawanan, maka pemungutan pajak harus memenuhi syarat. Syarat pemungutan pajak menurut Mardiasmo (2016:4) adalah sebagai berikut :

1. Pemungutan pajak harus adil (syarat keadilan)

2. Pemungutan pajak harus berdasarkan undang-undang (Syarat Yuridis)

3. Tidak mengganggu perekonomian (Syarat Ekonomi)

4. Pemungutan pajak harus efisien ( Syarat Finansiil)

5. Sistem pemungutan pajak harus sederhana

\section{Tarif Pajak}

1. Tarif Proporsional (sebanding)

Tarif proporsional adalah tariff dalam persentase tetap berapaun jumlah yang menjadi dasar pengenaan pajak, dan pajak yang harus dibayar selalu akan berubah sesuai dengan jumlah yang akan dikenakan.

2. Tarif Tetap

Tarif berupa jumlah yang tetap (sama terhadap berapapun jumlah yang dikenai pajak sehingga besarnya pajak terutang tetap).

3. Tarif Progresif (meningkat)

Tariff progresif adalah tariff dengan persentase yang semakin naik/meningkat apabila jumlah uang menjadi dasar pengenaan pajak naik atau meningkat (Siti. 2013: 14).

\section{Pajak Daerah}

Pajak Daerah dalam Undang-Undang Nomor 28 Tahun 2009 adalah kontribusi wajib kepada daerah yang terutang oleh orang pribadi ataubadan yang bersifat memaksa berdasarkan undang-undang, dengantidak mendapatkan imbalan secara langsung dan digunakan untukkeperluan daerah sebesar-besarnya kemakmuran rakyat.

\section{Jenis pajak daerah}

1. Pajak Hotel

2. Pajak Restoran

3. Pajak Hiburan

4. Pajak Reklame

5. Pajak Penerangan Jalan

6. Pajak Mineral bukan Logam dan Batuan

7. Pajak Parkiran

8. Pajak Air Tanah

9. Pajak Sarang Burung Walet

10.Pajak Bumi Bangunan pedesaan dan perkotaan 
11. Bea Perolehan hak atas tanah dan bangunan

\section{Retribusi Daerah}

Menurut Undang-Undang Nomor 28 Tahun 2009 retribusi daerah adalah pungutan daerah sebagai pembayaran atas jasa atau pemberian izin tertentu yang khusus disediakan dan/atau diberikan oleh pemerintah daerah untuk kepentingan orang pribadi atau badan.Retribusi daerah sebagaimana halnya dengan pajak daerah merupakan salah satu sumber Pendapatan Asli Daerah (PAD).

Adapun cirri-ciri retribusi menurut Haris (Adisasmita, 2011 : 86) sebagai berikut :

1. Pelaksanaan bersifat ekonomis

2. Ada imbalan langsung kepada yang membayar retribusi

3. Iurannya memenuhi persyaratan yaitu persyaratan formal dan material

4. Retribusi daerah merupakan pungutan yang umumnya budgetairnya tidak menonjol

5. Dalam hal-hal tertentu, tetapi dalam banyak hal tidak lebih dari pengembalian baiaya yang telah dibukakan oleh pemerintah daerah untuk memenuhi permintaan masyarakat.

Adapun jenis-jenis retribusi daerah sebagai berikut:

1. Retribusi Jasa Umum

2. Retribusi Jasa Usaha

3. Retribusi Perizinan Tertentu.

\section{Pendapatan Asli Daerah}

Pendapatan asli daerah adalah penerimaan yang diperoleh dari sektor pajak daerah, retribusi daerah, hasil perusahaan milik daerah, hasil pengeloalaan kekayaan daerah yang dipisahkan, dan lain-lain pendapatan asli daerah yang sah (Mardiasmo,2011:1). Pendapatan Asli Daerah mampu meningkatkan perekonomian daerah dan akan berdampak kepada perekonomian nasional. Tingkat pertumbuhan ekonomi menjadi salah satu tujuan penting pemerintah daerah maupun pemerintah pusat.

Sumber-sumber Pendapatan Asli Daerah (PAD) menurut pasal 6 ayat (1) Undang-undang Nomor 33 Tahun 2004 (UU No,33:2004) adalah sebagai berikut :

1. Pajak Daerah

2. Retribusi Daerah

3. Pendapatan Hasil Pengelolaan Kekayaan Daerah yang Dipisahkan

4. Lain-lain PAD yang Sah

Pengaruh Pajak Daerah terhadap Pendapatan Asli Daerah

Pajak daerah merupakan salah satu sumber Pendapatan Asli Daerah, dimana setiap peningkatan pajak daerah akan mempengaruhi peningkatan pada Pendapatan Asli Daerah (PAD). Dengan demikian, adanya hubungan antara pajak daerah dengan Pendapatan Asli Daerah (PAD) yaitu jika jumlah penerimaan pajak daerah mengalami kenaikan maka Pendapatan Asli Daerah (PAD) juga mengalami kenaikan (Kusuma 2013).

\section{Pengaruh Retribusi Daerah terhadap Pendapatan Asli Daerah}


Peran serta masyarakat dalam membayar retribusi sangat diharapkan untuk meningkatkan penerimaan retribusi daerah. Semakin besar jumlah penerimaan retribusi daerah maka akan semakin besar pula jumlah penerimaan Pendapatan Asli Daerah (PAD). Dengan demikian, adanya hubungan antara retribusi daerah dengan Pendapatan Asli Daerah (PAD) yaitu jika jumlah penerimaan retribusi daerah mengalami kenaikan maka Pendapatan Asli Daerah (PAD) juga mengalami kenaikan (Kusuma 2013).

\section{METODE PENELITIAN}

\section{Jenis Penelitian}

Jenis penelitian ini adalah penelitian field reaseach (studi lapangan) dan menggunakan pendekatan Kuantitatif .Field reaseach (studi lapangan) adalah suatu metode yang dilakukan oleh peneliti dengan cara pengamatan langsung terhadap kegiatan yang dilakukan oleh pereusahaan atau lembaga (Sunyoto. 2013 : 22) sedangkan pendekatan kuantitatif merupakan data yang memiliki kecendrungan dapat dianalisis dengan cara atau teknik statistik, data tersebut berupa angka atau skor (Sugiono. $2015: 23$ ).

\section{Teknik Analisis Data}

Untuk mencapai tujuan penelitian, maka penulis menngunakan anlisis statistik dengan bantuan (Statistical Product and Service Solutions) SPSS 24 for windows untuk mengukur pengaruh antara variabel independen dengan variabel dependen dan menguji hipotesis yang diajukan analisis digunakan untuk menerima atau menolak hipotesis tersebut. Adapun analisis statistik yang digunakan adalah sebagai berikut :

\section{Statistik Deskriptif}

Analisis statistk deskriptif merupakan penelitian yang dilakukan untuk mengetahui nilai variabel independen dan variabel dependen.Dalam analisis ini dilakukan pembahasan pengaruh pajak daerah dan retribusi daerah terhadap Pendapatan Asli Daerah (PAD) Kabupaten Lima Puluh Kota.

\section{Uji Hipotesis Regresi Ordinal}

Penguji hipotesis dalam penelitian ini menggunakan regresi ordinal.Regresi ordinal adalah regresi dimana variabel terkaitnya menggunakan skala ordinal. Sedangkan variabel bebasnya bisa merupakan Covariate(jika menggunakan skala interval atau rasio) atau bisa merupakan factor (jika menggunakan skala nominal atau ordinal).. (Ghozali 2012 : 94).

Prinsip yang digunakan dalam regresi ordinal adalah prinsip general least squar.Prinsip general least squar yaitu metode permodelan yang memprediksi probalitas kumulatif dari kategori yang ada. Jenis regresi ordinal mempunyai beberapa teknik perhitungan yang mana pada SPSS disebut dengan istilah Option Link, jenis tersebut adalah sebagai berikut:

1. Logit dengan persamaan $\mathbf{F}(\mathbf{x})=\log (\mathbf{x} /(\mathbf{1}-\mathbf{x}))$.

Jenis ini digunakan pada sebagian besar distribusi data, maka aplikasi SPSS secara default atau bahwa aslinya menggunakan Option Link jenis logit ini.

2. Negative log-log dengan persamaan $\mathbf{F}(\mathbf{x})=-\log (-\log (\mathbf{x}))$ 
Jenis ini digunakan apabila data mempunyai kecendrungan bernilai rendah

3. Complementary log-logdengan persamaan $\mathbf{F}(\mathbf{x})=\log (-\log (\mathbf{1}-\mathbf{x}))$

Jenis ini digunakan apabila data mempunyai kecendrungan bernilai tinggi

4. Cauchit(Inverse Cauchy) dengan persamaan $\mathbf{F}(\mathbf{x})=\tan (\mathbf{P h i}(\mathbf{X 0}, 05))$

Jenis ini digunakan apabila variabel latent mempunyai nilai ekstrim

5. Probitdengan persamaanF(x) =)-1(x)dengan nilai $0-1$ adalah fungsi inverse distribusi komulatif standar normal.

Jenis ini digunakan apabila variabel latent berdistribusi secara normal.

Semua jenis atau Option Linkdi atas tentu dipilih dengan menyesuiakan distribusi data yang ada. Dalam regresi ordinal jika variabel independen (Pajak daerah dan Retribusi daerah) memiliki pengaruh terhadap Pendapatan Asli Daerah (PAD). Maka persamaan regresinya adalah:

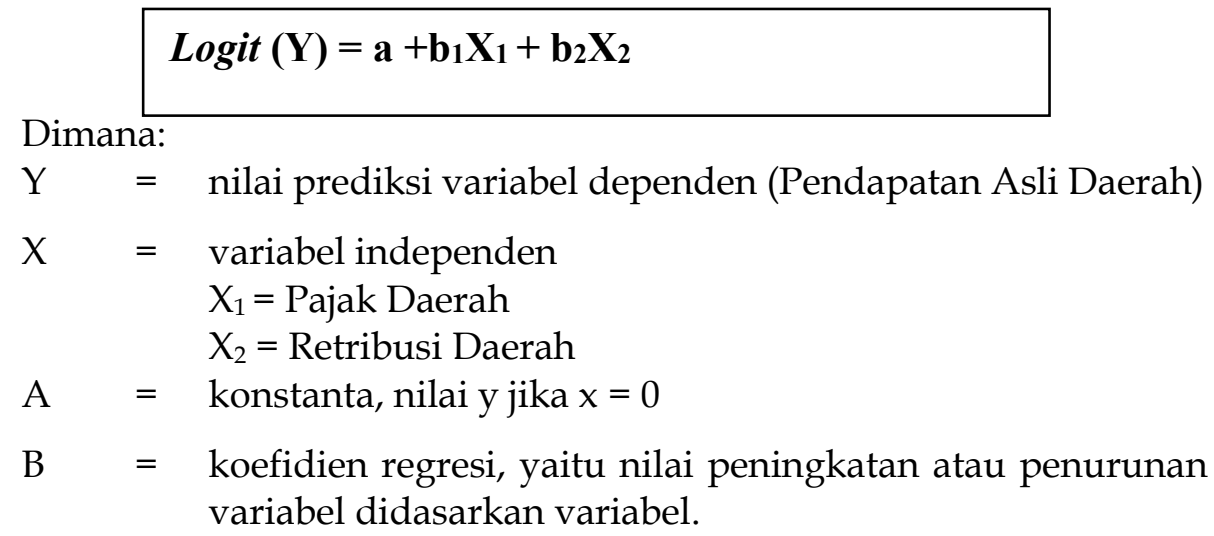

Dibawah ini merupakan pembagian uji hipotesis regresi ordinal adalah sebagai berikut:

1. Uji Keberartian Model

Jika variabel independen dimasukan kedalam model, maka nilai 2loglikehood akan turun dan penurunan ini signifikan pada 0,001 yang berarti model dengan variabel independen lebih baik dibandingkan hanya dengan model intercept saja. Sehingga dapat disimpulkan bahwa model fit (Ghozali 2012: 97).

2. Uji Kesesuaian Model

Uji kesesuaian model ini menunjukan uji kesesuaian model dengan data. Jika signifikan besar dari 0,05 hal ini berarti model data sesuai dengan data empiris dan model layak digunakan. Tabel yang terkait dengan kesesuaian model adalah sebagai berikut (Ghozali. 2012: 99) :

a. Tabel Pseudo-Square menjelaskan variansi variabel dependen yang dapat dijelaskan oleh variansi variabel independen dalam bentuk presentase.

b. Tabel Paramtr Estimates dilihat dengan berpedoman kepada nilai wald dan nilai signifikanya. Dasar pengambilan keputusan dalam tabel ini adalah jika nilai signifikan dari masing-masing wald pada variabel $X<0,05$ berarti terdapat pengaruh terhadap variabel dependen dari masing-masing variabel independen, 
sedangkan jika nilai signifikasi dari masing- masing Wald pada variabel $X>0,05$ berarti tidak terdapat pengaruh terhadap variabel dependen dari masing-masing variabel independen.

c. Tabel Test of Parallel Liner digunakan untuk asumsi bahwa semua kategori memiliki parameter yang sama atau tidak. Nilai yang diinginkan adalah signifikan yaitu > 0,05 yang berarti bahwa model cocok.

\section{HASIL DAN PEMBAHASAN}

\section{Hasil Penelitian}

1. Pajak Daerah

Data mengenai target dan realisasi pajak daerah dari tahun 2014 sampai dengan tahun 2018 dapat dilihat pada tabel 1.3 dibawah ini :

Tabel 1

Target dan Realisasi Pajak Daerah

Kabupaten Lima Puluh Kota Tahun 2014-2018

\begin{tabular}{|c|c|c|c|c|c|}
\hline No & Tahun & $\begin{array}{c}\text { Target Pajak } \\
\text { Daerah (Rp) }\end{array}$ & $\begin{array}{c}\text { Realisasi Pajak } \\
\text { Daerah (Rp) }\end{array}$ & $\begin{array}{c}\text { Persentase } \\
\text { Target } \\
\text { Pajak } \\
\text { Daerah (\%) }\end{array}$ & $\begin{array}{c}\text { Persentase } \\
\text { Realisasi } \\
\text { Pajak } \\
\text { Daerah (\%) }\end{array}$ \\
\hline 1 & 2014 & 11.186 .100 .000 & 11.662 .945 .822 & 100 & 105,08 \\
\hline 2 & 2015 & 13.141 .746 .335 & 12.104 .525 .551 & 100 & 95,11 \\
\hline 3 & 2016 & 15.532 .507 .900 & 14.060 .795 .573 & 100 & 90,52 \\
\hline 4 & 2017 & 19.841 .334 .790 & 17.666 .233 .262 & 100 & 89,04 \\
\hline 5 & 2018 & 23.500 .000 .000 & 20.369 .954 .187 & 100 & 86,68 \\
\hline
\end{tabular}

(Sumber : Badan Keuangan Kabupaten Lima Puluh Kota)

Dari tabel 1.3 di atas menujukan bahwa pajak daerah Kabupaten Lima Puluh Kota mengalami penurunan realisasi atau tidak mencapai target yang telah dianggarkan oleh pemerintah dari tahun 2015 sampai dengan tahun 2018. Pada tahun 2015 realisasi pajak daerah yang didapatkan oleh pemerintah Kabupaten Lima Puluh Kota sebesar Rp.12.104.525.551 atau 95,11\% sedangkan yang dianggarkan adalah sebesar Rp.13.141.746.335. Sedangkan pada tahun 2016 realisasi pajak daerah Kabupaten Lima Puluh Kota mengalami penurunan pencapaian realisasi dari tahun sebelumnya. Dimana tahun 2016 realisasi pajak daerah mencapai $90,52 \%$ mengalami penurunan sebesar $4,59 \%$. Pada tahun 2017 realisasi pajak daerah mengalami penurun kembali yaitu sebesar 1,48\% dan pendapatan realisasi nya adalah sebesar 89,04\%. Pada tahun 2018 realisasi pajak daerah Kabupaten Lima Puluh Kota kembali tidak mencapai target yang dianggarkan yaitu sebesarRp.23.500.000.000 dan realisasinya hanya mencapai Rp.20.369.954.187 atau $86,68 \%$.

\section{Retribusi Daerah}




\section{Tael 2}

Target dan Realisasi Retribusi Daerah

Kabupaten Lima Puluh Kota Tahun 2014-2018

\begin{tabular}{|c|c|c|c|c|c|}
\hline No & Tahun & $\begin{array}{c}\text { Target Retribusi } \\
\text { Daerah (Rp) }\end{array}$ & $\begin{array}{c}\text { Realisasi } \\
\text { Retribusi Daerah } \\
\mathbf{( R p )}\end{array}$ & $\begin{array}{c}\text { Persentas } \\
\text { e Target } \\
\text { Retribusi } \\
\mathbf{( \% )}\end{array}$ & $\begin{array}{c}\text { Persentase } \\
\text { Realisasi } \\
\text { Retribusi } \\
\text { Daerah (\%) }\end{array}$ \\
\hline 1 & 2014 & 10.595 .085 .850 & 8.225 .791 .648 & 100 & 77,92 \\
\hline 2 & 2015 & 4.894 .238 .693 & 5.353 .468 .296 & 100 & 109,38 \\
\hline 3 & 2016 & 5.452 .817 .100 & 4.158 .913 .425 & 100 & 76,27 \\
\hline 4 & 2017 & 4.700 .297 .110 & 4.413 .742 .556 & 100 & 93,90 \\
\hline 5 & 2018 & 6.933 .706 .000 & 4.986 .250 .191 & 100 & 71.91 \\
\hline
\end{tabular}

(Sumber : Badan Keuangan Kabupaten Lima Puluh Kota)

Dari tebel 1.4 diatas dapat dilihat bahwa realisasi retribusi daerah Kabupaten Lima Puluh Kota mengalami ketidak stabilan dalam penerimaan realisasinya. Pada tahun 2014 realisasi retribusi daerah Kabupaten Lima Puluh Kota tidak mencapai target yang dianggarkan oleh pemerintah, penerimaan realisasi pada tahun 2014 yaitu sebesar Rp.8.225.791.648 atau 77,92\% sedangkan yang dianggarkan adalah sebesar Rp.10.595.085.850. sedangkan dilihat pada tahun 2016 realisasi retribusi daerah kembali mengalami penurunan, realisasi yang dicapai pada tahun 2016 adalah sebesar Rp.4.158.913.425 atau 76,27\% sedangkan yang ditargetkan adalah sebesar Rp.5.452.817.100. dilihat pada tahun 2017 realisasi retribusi tidak mencapai target yang telah dianggarkan sebesar Rp.4.700.297.110 sedangkan realisanya adalah sebesar Rp.4.413.742.556 atau 93,90\%. Pada tahun 2018 realisasi retribusi daerah Kabupaten Lima Puluh Kota mengalami penurunan sebesar 21,99\% dimana pada tahun 2018 merupakan tahun terendah dalam pencapaian target retribusi daerah yaitu sebesar Rp.4.986.250.191 atau 71,91\% sedangkan yang ditargetkan adalah sebesar Rp.6.933.706.000.

\section{Statistik Deskriptif}

Statistik deskriptif memberikan gambaran atau deskriptif suatu data yang dilihat dari nilai rata (mean, standar deviasi, varian, maksimum, minimum, sum, range, kurtosis dan skewness (kemenangan distribusi) (Ghozali, 2016: 19). Analisis data dalam penelitian ini menggunakan data pendapatan pajak daerah, retribusi daerah dan Pendapatan Asli Daerah (PAD) dari Kabupaten Lima Puluh Kota.

Tabel 3

Hasil Uji Statistik Deskriptif

\begin{tabular}{|l|l|l|l|l|l|}
\hline Descriptive Statistics & (miliyar) \\
\hline & N & Minimum & Maximum & Mean & Std. Deviation \\
\hline
\end{tabular}




\begin{tabular}{|l|l|l|l|l|l|}
\hline Pajak Daerah & 5 & 11.662 & 20.369 & 15.172 .890 & 3.748 .251 \\
\hline $\begin{array}{l}\text { Retribusi } \\
\text { Daerah }\end{array}$ & 5 & 4.158 & 8.225 & 5.427 .633 & 1.633 .067 \\
\hline $\begin{array}{l}\text { Pendapatan } \\
\text { Asli Daerah }\end{array}$ & 5 & 52.620 & 118.881 & 72.166 .966 & 26.992 .238 \\
\hline $\begin{array}{l}\text { Valid N } \\
\text { (listwise) }\end{array}$ & 5 & & & & \\
\hline
\end{tabular}

Sumber : Hasil pengelolaan Spss 24

Tabel diatas menggambarkan deskripsi variabel-variabel statistik dalam penelitian. Minimum adalah nilai terkecil dari suatu rangkaian pengamatan.Maksimum yaitu nilai terbesar dari suatu pengamatan. Mean (rata-rata) adalah hasil dari penjumlahan nilai seluruh data dibagi dengan banyak data. Sedangkan standar deviasi adalah akar dari jumlah kuadrat dari selisih nilai data dengan rata-rata yang dibagi dengan banyak data. Dari tabel diatas terlihat deskripsi variabel penelitian dengan jumlah data setiap variabel yang valid adalah sebagai berikut:

1. Nilai minimum pajak daerah Kabupaten Lima Puluh Kota dari tahun 2014 sampai 2018 yaitu sebesar Rp. 11.662 dan nilai maksimum pajak daerah Kabupaten Lima Puluh Kota adalah sebesar Rp.20.369 sedangkan nilai ratarata (mean) pajak daerah Kabupaten Lima Puluh Kota adalah sebesar Rp.15.172.890

2. Nilai minimum retribusi daerah Kabupaten Lima Puluh Kota dari tahun 2014 sampai tahun 2018 adalah sebesar Rp.4.158dan nilai maksimum retribusi daerah Kabupaten Lima Puluh Kota yaitu sebesar Rp.8.225sedangkan nilai rata-rata (mean) retribusi daerah adalah sebesar Rp.5.427.633

3. Nilai minimum Pendapatan Asli Daerah (PAD) Kabupaten Lima Puluh Kota dari tahun 2014 sampai tahun 2018 adalah sebesar Rp.52.620 dan nilai maksimum Pendapatan Asli Daerah (PAD) Kabupaten Lima Puluh Kota adalah sebesar Rp.118.881 sedangkan nilai rata-rata (mean) Pendapatan Asli Daerah (PAD) Kabupaten Lima Puluh Kota adalah Rp.72.166.966

4. Standar deviasi pajak daerah dari tahun 2014 sampai 2018 yaitu sebesar Rp.3.748.251 sedangkan nilai standar deviasi untuk retribusi daerah dari tahun 2014 sampai 2018 adalah sebesar Rp.1.633.067 dan nilai standar deviasi Pendapatan Asli Daerah (PAD) yaitu sebesar Rp.26.992.238

\section{Uji Hipotesis Regresi Ordinal}

Prinsip yang digunakan dalam regresi ordinal adalah prinsip general square, prinsip ini adalah permodelan yang memprediksi probalitas kumulatif dari kategori yang ada.

1. Uji Keberartian Model

Jika variabel independen dimasukan kedalam model, maka nilai 2loglikelihood akan turun dan penurunan ini signifikan pada 0,001 yang berarti model dengan variabel independen lebih baik dibandingkan hanya dengan model intercept saja. Sihingga dapat disimpulkan bahwa model fit. Berikut adalah hasil Uji keberartian model variabel penelitian sebagai berikut :

Tabel 4 
Hasil Pengujian Uji Keberatian Model

\begin{tabular}{|l|r|r|r|r|}
\hline \multicolumn{1}{|l|}{ Model Fitting Information } \\
\hline Model & -2 Log Likelihood & Chi-Square & df & Sig. \\
\hline $\begin{array}{l}\text { Intercept } \\
\text { Only }\end{array}$ & 16,094 & & & \\
\hline Final &, 000 & 16,094 & 4 & \\
\hline Link function: Logit.
\end{tabular}

Sumber : Hasil pengelolaan Spss 24

Berdasarkan tabel 4.4 di atasmodel lainya dengan intercept saja menghasilkan nilai 2 loglikelihood sebesar 16,094, sedangkan jika variabel independen $X_{1}$, dan $X_{2}$, dimasukan kedalam model ini, maka nilai 2 loglikelihood turun monejadi 0,000 dan penurunan ini signifikan pada 0,001yang berarti model ini lebih dibandingkan hanya dengan intercept saja. Jadi, dapat disimpulkan bahwa model fit.

\section{Uji Kesesuaian Model}

Uji kesesuaian model ini menunjukan uji kesesuaian model dengan data. Jika signifikansi besar dari 0,05 hal ini berarti model sesuai dengan data empiris dan model layak digunakan. Berikut hasil uji kesesuaian model variabel penelitian sebagai berikut :

Tabel 5

Hasil Uji kesesuaian Model

\begin{tabular}{|l|r|r|r|}
\hline Goodness-of-Fit & Chi-Square & df & Sig. \\
\hline Model &, 219 & 12 & \\
\hline Pearson &, 538 & 12 & 1,000 \\
\hline Deviance & \multicolumn{4}{|l}{} \\
\hline Link function: Logit.
\end{tabular}

Sumber : Hasil pengelolaan Spss 24

Berdasarkan tabel 4.5 di atas menunjukan uji kesesuaian model dengan data pearson sebesar 0,219 dan nilai signifikansi sebesar 1,000 besar dari 0,05 $(1000>0,05)$ dan Devience sebesar 0,538 dengan signifikansi 1,000 besar dari $0,05(1,000>0,05)$. Hal ini berarti model sesuai dengan data empiris dan model layak digunakan.

Tabel yang terkait dengan kesesuaian model adalah sebagai berikut :

1. Tabel Pseudo-Square menjelaskan variabel variabel dependen yang dapat dijelaskan oleh variansi variabel independen dalam bentuk presentase.

Berikut hasil pengujian tabel pseudo-squarevariabel penelitian sebagai berikut:

Tabel 6

Hasil uji tabel Pseudo-Square

\begin{tabular}{|l|r|}
\hline Pseudo R-Square \\
\hline Cox and Snell &, 960 \\
\hline Nagelkerke & 1,000 \\
\hline
\end{tabular}




\begin{tabular}{|l|r|}
\hline McFadden & 1,000 \\
\hline Link function: Logit. \\
\hline
\end{tabular}

Sumber : Hasil pengelolaan Spss 24

Berdasarkan tabel 4.6 di atas tabel Pseudo R-Squaref menjelaskan pengaruh pajak daerah dan retribusi daerah terhadap Pendapatan Asli Daerah (PAD) sebesar 96\% dan nilai nagelkerke sebesar 1,000 atau $100 \%$.

1. Tabel Parameter Estimatesdilihat dengan berpedoman kepada nilai wald dan nilai signifikansinya. Dasar pengambilan keputusan dalam tabel Parameter Estimatesadalah jika nilai signifikansi dari masing-masing wald pada variabel $\mathrm{X}<0,05$, berarti terdapat pengaruh terhadap variabel dependen dari masing-masing variabel independen, sedangkan jika nilai signifikansi dari masing-masing wald pada variabel $X>0,05$, berarti tidak terdapat pengaruh terhadap variabel dependen dari masing-masing variabel independen. Berikut hasil pengujian tabel Parameter Estimatesvariabel penelitian sebagai berikut:

Tabel 7

Hasil Uji Tabel Parameter Estimates

\begin{tabular}{|c|c|c|c|c|c|c|c|}
\hline \multicolumn{8}{|c|}{ Parameter Estimates } \\
\hline \multirow[b]{2}{*}{ Model } & \multirow[b]{2}{*}{ Estimate } & \multirow[b]{2}{*}{$\begin{array}{l}\text { Std. } \\
\text { Error }\end{array}$} & \multirow[b]{2}{*}{ Wald } & \multirow[b]{2}{*}{$\mathrm{df}$} & \multirow[b]{2}{*}{ Sig. } & \multicolumn{2}{|c|}{$\begin{array}{l}\text { 95\% Confidence } \\
\text { Interval }\end{array}$} \\
\hline & & & & & & $\begin{array}{l}\text { Lower } \\
\text { Bound }\end{array}$ & $\begin{array}{l}\text { Upper } \\
\text { Bound }\end{array}$ \\
\hline \multirow{4}{*}{$\begin{array}{l}\text { Threshold } \\
{[R Y=1000]} \\
{[R Y=2000]} \\
{[R Y=3000]} \\
{[R Y=4000]}\end{array}$} & 628,968 & 40,898 & 1,502 & 1 & 149 & $-109,128$ & 51,191 \\
\hline & 617,060 & 29,872 & 1,326 & 1 & 238 & $-75,607$ & 41,488 \\
\hline & 635,815 & 18,368 & 100 & 1 & 223 & $-41,817$ & 30,186 \\
\hline & 676,094 & 21,094 & 1,083 & 1 & 113 & $-35,251$ & 47,438 \\
\hline \multirow[t]{2}{*}{ Location $\mathrm{X} 1$} & 6,346 & 57,222 & 1,403 & 1 & ,002 & $-148,499$ & 75,807 \\
\hline & $-2,875$ & 35,067 & 1,426 & 1 & ,064 & $-91,606$ & 45,856 \\
\hline
\end{tabular}

Sumber : Hasil pengelolaan Spss 24

Berdasarkan tabel 4.7 di atas diperoleh nilai wald $X_{1}$ sebesar 1,403 dengan nilai signifikansinya sebesar 0,002 $(0,002<0,05)$, yang berarti bahwa $X_{1}$ memiliki penaruh terhadap variabel dependen yaitu adanya pengaruh pajak daerah terhadap Pendapatan Asli Daerah (PAD), sedangkan nilai $\mathrm{X}_{2}$ dilihat dari nilai wald sebesar 1,426 dan nilai signifikansinya adalah $0,064(0,064>0,05)$ yang berarti tidak terdapat pengaruh antara retribusi daerah terhadap Pendapatan Asli Daerah. 
1. Tabel Test of Parallel Linesdigunakan untuk asumsi bahwa semua kategori memiliki parameter yang sama atau tidak. Nilai yang didinginkan adalah tidak signifikan yaitu $>0,05$ yang berarti bahwa model cocok. Berikut hasil pengujian Tabel Test of Parallel Lines variabel penelitian sebagai berikut :

Tabel 8

Hasil uji Tabel Test of Parallel Lines

\begin{tabular}{|l|l|r|r|r|}
\hline \multicolumn{2}{|l|}{ Test of Parallel Lines } \\
\hline Model & $\begin{array}{l}\text {-2 Log } \\
\text { Likelihood }\end{array}$ & Chi-Square & df & Sig. \\
\hline $\begin{array}{l}\text { Null } \\
\text { Hypothesis }\end{array}$ & 000 & & & \\
\hline General &, $000^{\mathrm{b}}$ &, 000 & 12 & 1,000 \\
\hline
\end{tabular}

The null hypothesis states that the location parameters (slope coefficients) are the same across response categories.

a. Link function: Logit.

b. The log-likelihood value is practically zero. There may be a complete separation in the data. The maximum likelihood estimates do not exist.

Sumber : Hasil pengelolaan Spss 24

Berdasarkan tabel 4.8 di atas digunakan untuk menguji asumsi bahwa setiap kategori mempunyai parameter yang sama atau hubungan antara variabel independen dengan logit adalah sama untuk semua persamaan logit, dengan nilai signifikansinya sebesar 1,000 besar dari 0,05 $(1,000>0,05)$ maka model yang dihasilkan parameter yang sama sehingga penilian link functiondapat disimpulkan bahwa link functionnya sesuai.

Dari hasil pengujian hipotesis regresi ordinal diatas, maka persamaan regresinya adalah :

$\operatorname{Logit}(\mathrm{Y})=\mathrm{a}+\mathrm{b}_{1} \mathrm{X}_{1}+\mathrm{b}_{2} \mathrm{X}_{2}$ daerah)

Pendapatan Asli Daerah $=16,094+6,346$ (pajak daerah) -2,875(retribusi

Dari persamaan di atas, mempunyai arti yang dapat disimpulkan bahwa :

1. a (Konstanta) $=16,094$ (Tabel Model Fitting Information)

Artinya bahwa pada variabel pajak daerah dan retribusi daerah tidak ada atau dalam keadaan konstan atau nol, maka Pendapatan Asli Daerah Kabupaten Lima Puluh Kota sebesar 16,094 dengan asumsi faktorfaktor lain dianggap konstan atau nol.

2. $\mathrm{X}_{1}$ (Pajak Daerah) $=6,346$ (Tabel Parameter Estimates)

Artinya, pajak daerah menunjukan ada pengaruh terhadap Pendapatan Asli Daerah dan berpola positif. Apabila terjadi kenaikan pada variabel Pajak daerah dalam satu satuan, maka Pendapatan Asli Daerah mengalami kenaikan sebesar 6,346 dimana faktor lainya dalam keadaan kosntan atau nol.

3. $\mathrm{X}_{2}$ (Retribusi Daerah) $=-2,875$ (Tabel Parameter Estimates)

Artinya, retribusi daerah menunjukan tidak ada pengaruh terhadap Pendapatan Asli Daerah (PAD) dan berpola negatif. Apabila terjadi penurunan pada variabel retribusi daerah dalam satu satuan, maka 
Pendapatan Asli Daerah (PAD) mengalami penurunan sebesar -2,875 dimana faktor lainya dalam keaadan konstan atau nol.

\section{PEMBAHASAN}

\section{Pajak Daerah}

Berdasarkan hasil pengujianTabel 4.7 Parameter Estimates di peroleh hasil signifikansinnya 0,002 < 0,05 berarti pajak daerah berpengaruh terhadap Pendapatan Asli Daerah Kabupaten Lima Puluh Kota dapat disimpulkan bahwa $\mathrm{H}_{\mathrm{a} 1}$ diterima dan $\mathrm{H}_{01}$ ditolak.

\section{Retribusi Daerah}

Berdasarkan hasil pengujian pada tabel 4.7 Parameter Estimates memperoleh nilai signifikansi sebesar $0,064>0,05$ yang berarti $\mathrm{H}_{\mathrm{a} 2}$ ditolak dan $\mathrm{H}_{02}$ diterima yaitu retribusi daerah tidak berpengaruh terhadap Pendapatan Asli Daerah (PAD) Kabupaten Lima Puluh Kota karena kecilnya pendapatan retribusi daerah di Kabupaten Lima Puluh Kota selama 2014, 2016 sampai 2018 kecuali 2015, namun retribusi daerah merupakan salah satu sumber penerimaan Pendapatan Asli Daerah (PAD) di Kabuapten Lima Puluh Kota tetapi tidak berpengaruh terhadap tingkat Pendapatan Asli Daerah (PAD).

\section{Pendapata Asli Daerah}

Berdasarkan analisis data di atas diketahui secara simultan bahwa pajak daerah dan retribusi daerah berpengaruh terhadap Pendapatan Asli Daerah (PAD) Kabupaten Lima Puluh Kota. Secara keseluruhan jika dilihat dari tabel yaitu tabel uji Pseudo R-Square secara simultan pajak daerah dan retribusi daerah berpengaruh terhadap Pendapatan Asli Daerah (PAD) sebesar 0,960 atau 96\% yang ditandai dengan nilai signifikansi final dari data menunjukan nilai sebesar 0,001 yang berarti kecil dari nilai signifikansi $0,05(0,001<0,05)$, hal ini juga menunjukan bahwa $\mathrm{H}_{\mathrm{a}}$ diterima dan $\mathrm{H}_{03}$ ditolak. Semakin tinggi pendapatan pajak daerah dan retribusi daerah akan berpengaruh kepada tingkat Pendapatan Asli Daerah Kabupaten Lima Puluh Kota.

\section{KESIMPULAN DAN KONTRIBUSI PENELITIAN}

\section{Kesimpulan}

Dari hasil penelitian dapat diambil kesimpulan sebagai berikut :

1. Hasil pengujian Tabel 4.7 Parameter Estimates di peroleh hasil signifikansinnya $0,002<0,05$ berarti pajak daerah berpengaruh terhadap Pendapatan Asli Daerah Kabupaten Lima Puluh Kota dapat disimpulkan bahwa $\mathrm{H}_{\mathrm{a} 1}$ diterima dan $\mathrm{H}_{01}$ ditolak. Hasil pengujian pada tabel 4.7 Parameter Estimates memperoleh nilai signifikansi sebesar 0,064>0,05 yang berarti $\mathrm{H}_{\mathrm{a} 2}$ ditolak dan $\mathrm{H}_{02}$ diterima yaitu retribusi daerah tidak berpengaruh terhadap Pendapatan Asli Daerah (PAD) Kabupaten Lima Puluh Kota.

2. Hasil pengujian padatabel 4.6 yaitu tabel uji Pseudo R-Square secara simultan pajak daerah dan retribusi daerah berpengaruh terhadap Pendapatan Asli Daerah (PAD) sebesar 0,960 atau 96\% yang ditandai dengan nilai signifikansi final dari data menunjukan nilai sebesar 0,001 yang berarti kecil dari nilai 
signifikansi $0,05(0,001<0,05)$, hal ini juga menunjukan bahwa $\mathrm{H}_{\mathrm{a} 3}$ diterima dan $\mathrm{H}_{03}$ ditolak.

\section{Saran}

Berdasarkan kesimpulan dan keterbatasan pada penelitian ini, maka dapat disampaikan saran sebagai berikut:

1. Bagi Pemerintah Daerah

Pemerintah daerah sebaiknya berkonsentrasi untuk meningkatkan penerimaan Pendapatan Asli Daerah (PAD) karena pemerintah akan semakin mudah membiyai kegiatan-kegiatan dan keperluan daerah yang nantinya akan meningkatkan kinerja pemerintah daerah. Selain itu, peningkatan Pendapatan Asli Daerah (PAD) akan bepengaruh terhadap fasilitas-fasilitas bagi masyarakat, dengan kata lain adanya peningkatan Pendapatan Asli Daerah (PAD) diharapkan akan menigkatkan kesejahteraan Penduduk.

2. Bagi Peneliti Selanjutnya

Penelitian selanjutnya diharapkan dapat mengembangkan penelitian dengan faktor atau variabel lain yang mempengaruhi Pendapatan Asli Daerah (PAD).

\section{DAFTAR PUSTAKA}

Abdul Halim. 2012. Akuntansi Keuangan Daerah Edisi 4. Jakarta : Salemba Empat

Abdul Halim \& Syam Kusufi. 2012.Akuntansi Sektor Publik.Jakarta : Salemba Empat

Abut,Halarius. 2010. Perpajakan Indonesia.Jakarta : Diadit Media

. 2012. Perpajakan Indonesia. Jakarta : Diadit Media

Adriani. 2013. Teori Perpajakan. Jakarta : Salemba Empat

Anggraei, Dina. 2010. Ananlisis Pengaruh Penerimaan Pajak Daerah dan Retribusi Daerah Terhadap Peningkatan Pendapatan Asli Daerah Provinsi Bengkulu.Universitas Islam Negeri Syarif Hidayatulloh. Jakarta

Danang, Sunyoto. 2013. Metodelogi Penelitian Akuntansi. Bandung : PT Refika Aditama Anggota Ikapi.

Dhia Wenny, Cherry. 2012. Analisis Pengaruh Pendapatan Asli Daerah (PAD) Terhadap Kinerja Keuangan Pada Pemerintahan Kabupaten dan Kota Di Provinsi Sumatera Selatan. Jurnal Ilmia STIE MDP, Volume 2, No.1.

Diana Sari. 2013. Konsep dasar Perpajakan.Bandung : Mitra Wacana Media

Gampito. 2012. Menggapai Ekonomi Islam.Juris (Jurnal Ilmiah Syariah), Volume 11, Nomor 2. Desember 2012 hal. 132-143

Ghozali, Imam. 2012. Aplikasi Analisis Multivariate dengan program IBM SPSS20.Semarang :Badan Penerbit-Universitas Deponegoro.

Mardiasmo. 2011. Perpajakan. Yogyakarta : Penerbit Andi 
Meilda Ellysa Putri, Sri Rahayu (2015). Pengaruh Pajak Daerah Dan RetribusiDaerah Terhadap Pendapatan Asli Daerah Kabupaten Cirebon Tahun Anggaran 2010-2014.eProceeding of Management : Vol.2, No.1

Mentayani, dkk.(2014). Pengaruh Penerimaan Pajak Daerah dan Retribusi DaerahTerhadap Pendapatan Asli Daerah Pada Kabupaten dan Kota di Provinsi Kalimantan Selatan.Jurnal Ekonomi dan Bisnis.Vol.07, No. 01.

Md. Krisna Arta Anggar Kusuma1 Ni Gust. Putu Wirawati (2013). Analisis PengaruhPenerimaan Pajak Daerah Dan Retribusi Daerah Terhadap PeningkatanPad Sekabupaten/Kota Di Provinsi Bali.E-Jurnal Akuntansi UniversitasUdayana.Vol 5.No 3.

Resmi, Siti. 2013. Perpajakan Teori dan Kasus.Jakarta : Salemba Empat

Riandani Rezki Prana.(2016).Analisis Faktor-faktor yang Mempengaruhi PendapatanAsli Daerah (PAD) Kota Tebing Tinggi. E-Jurnal Sekolah Tinggi Ilmu Manajemen Sukma. Vol. 4, No. 1, pp. 74-86.

Santoso, Singgih. 2012. Panduan Lengkap SPSS versi 20. Jakarta : PT Elex Media

Sihiaan, M.P. 2010.Pajak daerah dan Retribusi Daerah.Jakarta : Rajawali

. 2012. Pajak daerah dan Retribusi Daerah. Jakarta : Rajawali

Siregar, Syofian. 2010. Metode Penelitian Kuantitatif.Jakarta : PT Fajar InterpratamaMandiri.

Suandy, Erly. 2011. Hukum Pajak. Jakarta : Salemba Empat

Sugiarto, E.(2016).Analisis Kontribusi Perusahaan Daerah Pasar Terhadap PeningkatanPendapatan Asli Daerah di Kabupaten Lamongan. Jurnal penelitian ilmu Manajemen. 3 (1), 166-174.

Sugiyono.2014. Metode Penelitian Kuantitatif dan Kombinasi.Bandung : Alfabeta 2015. Metode Penelitian Kuantitatif Kualitatif dan RED.Bandung : Alfabeta

Undang-Undang Nomor 28 Tahun 2009 Tentang Retribusi Daerah

Undang-undang Nomor 32 tahun 2004 Tentang Pemerintahan Daerah

Undang-undang Nomor 33 tahun 2004 Tentang Perimbangan Keuangan Daerah

Waluyo. 2010. Perpajakan Indonesia. Jakarta : Salemba Empat. 